\title{
Kenaf Bast Fibers_-Part I: Hermetical Alkali Digestion
}

\author{
Jinshu Shi, ${ }^{1}$ Sheldon Q. Shi, ${ }^{1}$ H. Michael Barnes, ${ }^{1}$ Mark Horstemeyer, ${ }^{2}$ \\ Jinwu Wang, ${ }^{1}$ and El-Barbary M. Hassan ${ }^{1}$ \\ ${ }^{1}$ Forest Products Department (FPD), Mississippi State University (MSU), Box 9820, Starkville, MS 39762-9601, USA \\ ${ }^{2}$ Center for Advanced Vehicular Systems (CAVS), Box 5405, Starkville, MS 39762-5405, USA \\ Correspondence should be addressed to Sheldon Q. Shi, sshi@cfr.msstate.edu
}

Received 1 April 2011; Accepted 16 May 2011

Academic Editor: Susheel Kalia

Copyright ( 2011 Jinshu Shi et al. This is an open access article distributed under the Creative Commons Attribution License, which permits unrestricted use, distribution, and reproduction in any medium, provided the original work is properly cited.

\begin{abstract}
The objective of this study was to develop a hermetical alkali digestion process to obtain single cellulosic fibers from kenaf bast. Kenaf bast were hermetically digested into single fiber using a 5\% sodium hydroxide solution for one hour at four different temperatures $\left(80^{\circ} \mathrm{C}, 110^{\circ} \mathrm{C}, 130^{\circ} \mathrm{C}\right.$, and $\left.160^{\circ} \mathrm{C}\right)$. The hermetical digestion process used in this study produced fibers with high cellulose content (84.2-92.3\%) due to the removal of lignin and hemicelluloses. The surface hardness and elastic modulus of the fibers digested at $130^{\circ} \mathrm{C}$ and $160^{\circ} \mathrm{C}$ were improved significantly compared with those digested at $80^{\circ} \mathrm{C}$. The tensile modulus and tensile strength of the individual fibers reduced as the digestion temperature increased from $110^{\circ} \mathrm{C}$ to $160^{\circ} \mathrm{C}$. Micropores were generated in fiber cell wall when the fibers were digested at $130^{\circ} \mathrm{C}$ and $160^{\circ} \mathrm{C}$. The studies on the composites that were made from polypropylene reinforced with the digested fibers indicated that the compatibility between the digested fibers and polypropylene matrix was poor.
\end{abstract}

\section{Introduction}

Kenaf (Hibiscus cannabinus) an agricultural crop, is in the Malvaceae family, belonging to the division of Magnoliophyta. The history of kenaf cultivation can be traced back to ancient Africa [1]. Kenaf grows very quickly, rising to the heights of 12 to 14 feet in 4 to 5 months. In the United States, kenaf is mainly cultivated in Mississippi, Texas, and California, and so forth. Kenaf yields six to eight metric tons of bast and core per acre annually [1].

Kenaf bast fiber is a lignocellulosic fiber that has been used for pulp, paper, and textiles [2]. It is a good potential reinforcement material for polymer composites [3-8]. The lignocellulosic fiber mainly consists of cellulose, hemicelluloses, and lignin. Noncellulosic substances such as lignin, hemicelluloses, and pectins hold the cellulose fibrils together. The reinforcement effect for the lignocellulosic fiber is influenced by its cellulose content. Usually, high cellulose content can be obtained from the chemical retting [2, 9-14]. Retting is a term to describe a process to digest wood and agricultural stalks, especially bast crop stalks, into fibers. Alkali treatment is a standard procedure used in pulp and paper industries to remove lignin [15]. Through the alkali digestion process, individual fibers can be obtained by separating the fiber bundles. A uniform fiber distribution in the polymer composites may be easily achieved by using the individual fibers as reinforcements. In addition, micropores in the fiber can be created [16], which provide spaces for downstream fiber treatment such as nanoparticle impregnation, and so forth.

In a hermetically alkali digestion process, the temperature is the most influential factor affecting fiber quality and determines the pressure level of the autogneous vapor. High vapor pressure improves the penetration of digesting agents and accelerates the digestion process. The objective of this study was to investigate the effect of four digestion temperatures on the characteristics of kenaf bast fibers in hermetical alkali digestion process and to evaluate the reinforcement effects of the digested fibers in polymer composites.

\section{Materials and Methods}

2.1. Materials. Kenaf stalks were obtained from MSU North Farm. After the separation of the kenaf core and bast, the bast was cut into $50.8 \mathrm{~mm}$ lengths and dried to a moisture content of $7.4 \%$ at $103^{\circ} \mathrm{C}$. Sodium hydroxide $(\mathrm{NaOH})$ solution $(5 \%, \mathrm{w} / \mathrm{v})$ prepared with $\mathrm{NaOH}$ beads (Lab grade, 
Thermo Fisher Scientific Inc.) and distilled water was used as digestion agent. Glacial acetic acid (17.4 N, Regent grade, Thermo Fisher Scientific Inc.) was used as a $\mathrm{pH}$ neutralizer. Polypropylene (PP) film (CO-EX Oriented Polypropylene), provided by Plastic Suppliers, Inc. Dallas, TX, was used to fabricate the laminated kenaf fiber-PP composites.

2.2. Hermetical Alkali Digestion. Kenaf bast fiber was digested with $5 \% \mathrm{NaOH}$ solution (fiber: $\mathrm{NaOH}$ solution = $1: 30 \mathrm{~g} / \mathrm{mL}$ ) in a hermetical reactor (Parr Instrument Co. $251 \mathrm{M})$ for one hour at four temperatures $\left(80^{\circ} \mathrm{C}, 110^{\circ} \mathrm{C}\right.$, $130^{\circ} \mathrm{C}$, and $160^{\circ} \mathrm{C}$ ). The autogenous vapor pressures were $0.05 \mathrm{MPa}$ at $80^{\circ} \mathrm{C}, 0.15 \mathrm{MPa}$ at $110^{\circ} \mathrm{C}, 0.27 \mathrm{MPa}$ at $130^{\circ} \mathrm{C}$, and $0.60 \mathrm{MPa}$ at $160^{\circ} \mathrm{C}$. After digestion, the $\mathrm{pH}$ value of the fiber suspension was adjusted to 7.0 using acetic acid. The neutralized fibers were washed with tap water in order to remove the chemicals. Finally, the digested fibers were freeze dried for further analysis or oven dried for composites fabrication.

2.3. Digested Fiber/PP Composites Fabrication. The fibers digested at $80^{\circ} \mathrm{C}, 110^{\circ} \mathrm{C}$, and $130^{\circ} \mathrm{C}$ were long fiber bundles. These fiber bundles were mechanically separated using a blender (Oster 6791) for five minutes. The disintegrated fibers could be dispersed in water and made into uniform fiber sheets. The fibers digested at $160^{\circ} \mathrm{C}$ had a better dispersion in water and could be made into uniform fiber sheets directly without further mechanical separation. For the fiber sheet forming, the fibers were first dispersed in water by vigorous stirring. The suspension was then passed through a screen (mesh 35), on which the fiber sheets were formed. The fiber sheets were dried at $80^{\circ} \mathrm{C}$. The fiber sheets and polypropylene films were cut into $15.2 \mathrm{~cm} \times 15.2 \mathrm{~cm}$ and layered in alternate fiber directions. The weight ratio of fiber to polypropylene was 50:50. The laminated mats were hot pressed at a temperature of $200^{\circ} \mathrm{C}$ and a pressure of $0.7 \mathrm{MPa}$ for 2.5 minutes. The pressure was not released until the platen was cooled down to the room temperature. The laminated kenaf fiber/PP panels were removed from the press and stored in a desiccator for two days before the specimen preparation for mechanical testing. Three panels were fabricated for each digested fiber type.

2.4. Chemical Components and Yields. Chemical components, including holocellulose, $\alpha$-cellulose, Klason lignin, and ash content were determined for both the raw kenaf bast fibers and the digested fibers. The ash contents were measured following the procedure described in TAPPI standard T 211-om. 93 [17]. The determination of Klason lignin was based on the constituent insoluble in $72 \%$ sulfuric acid, which was estimated in accordance with the method \#482 from the Institute of Paper Chemistry [18]. Holocellulose is the total polysaccharide fraction (cellulose and hemicelluloses) of the fibers and was estimated according to the method of Wise et al. [19]. Alpha cellulose is the part of cellulose which does not dissolve in $17.5 \%$ sodium hydroxide solution. The alpha cellulose was determined in accordance with the method from German Association of Cellulose Chemists and Engineers [20]. The yields of the digested fibers were obtained based on the ratio of the ovendry weights of the resultant fibers to the original weight of the raw kenaf bast fibers.

2.5. Fiber Surface Morphology. A Zeiss SupraTM 40-Gemini Scanning Electron Microscope (SEM) with an accelerating voltage of $15 \mathrm{kV}$ was used for studying the morphology of the digested fibers. The fibers were treated with $15 \mathrm{~nm}$ gold sputter coating before being scanned in SEM. Seventy fibers from each digestion temperature were randomly selected, and the images were taken with the SEM. The dimensions of the fibers were measured by the image analysis. The distributions of their length, diameter, and aspect ratio were statistically analyzed.

2.6. Fiber Surface Hardness and Elastic Modulus. A Hysitron TriboIndenter with a Berkovich diamond tip was used to test the surface hardness and elastic modulus at a $400 \mu \mathrm{N}$ peak force and a $40 \mu \mathrm{N} / \mathrm{s}$ loading rate using a 10 -second segment time. The single fibers were mounted in a hardened epoxy matrix, and the load was perpendicular to the longitudinal direction of the fibers. According to the elastic punch theory and the method of Oliver and Pharr [21], the reduced elastic modulus was obtained based on the elastic contact stiffness.

2.7. Tensile Properties of Single Fibers. The single-fiber tests were conducted at the International Center for bamboo and Rattan (ICBR), Beijing, China, using a newly developed microtester (SF-I) [22]. Thirty individual kenaf fibers chemically digested at $110^{\circ} \mathrm{C}$ and $160^{\circ} \mathrm{C}$ were tested for tensile modulus and strength. The nominal gauge length was $0.7 \mathrm{~mm}$, and the cross-head speed was $0.8 \mathrm{~m} / \mathrm{s}$. A multiple comparison with Fisher's least significance difference (LSD) method at $\alpha=0.05$ was carried out with SAS software (SAS Institute Inc. NC, USA).

2.8. Mechanical Properties of the Composites. Dog boneshaped samples were cut from kenaf fiber/PP panels in accordance with ASTM 1037 [23] for the tension testing. The samples were stored in the desiccators with silica gel at the bottom for one week before they were used for mechanical tests. Tensile modulus and tensile strength of kenaf fiber/PP composites were tested using Instron 5869 (50 kN load cell) according to ASTM 1037. Nine replicates of each composite formulation were used. Multiple comparison of the results was conducted with Fisher's Least Square method at $\alpha=$ 0.05 using SAS 9.2 software (SAS Institute Inc. NC, USA). The fracture surfaces of the samples were observed using scanning electron microscopy (SEM, Zeiss Supra TM 40).

\section{Results and Discussion}

3.1. Fiber Yields and Chemical Compositions. Table 1 shows the yields and chemical composition of digested fibers and control fibers. It is shown that the fiber yield is gradually decreased as the digestion temperature increased. This result can be attributed to the removal of lignin and low molecular weight compounds as well as solubilization of hemicelluloses in hot alkali solution. 
TABLE 1: Yields and chemical compositions of the digested fibers.

\begin{tabular}{|c|c|c|c|c|c|c|}
\hline \multirow{2}{*}{ Digestion temperature $\left({ }^{\circ} \mathrm{C}\right)$} & \multirow{2}{*}{ Yield (\%) } & \multicolumn{5}{|c|}{ Chemical composition (\%) } \\
\hline & & Holocellulose & $\alpha$-cellulose & Hemicellulose* & Lignin & Ash \\
\hline (Control fiber) & & 75.8 & 46.0 & 29.8 & 19.1 & 5.1 \\
\hline 80 & 56.8 & 84.1 & 81.4 & 2.7 & 10.5 & 3.0 \\
\hline 110 & 57.3 & 85.8 & 84.0 & 1.8 & 10.0 & 3.2 \\
\hline 130 & 53.2 & 87.8 & 86.6 & 1.2 & 8.1 & 2.8 \\
\hline 160 & 44.6 & 94.2 & 92.3 & 0.9 & 0.24 & 2.7 \\
\hline
\end{tabular}

${ }^{*}$ Hemicellulose content is calculated from the difference between holocellulose and $\alpha$-cellulose content.

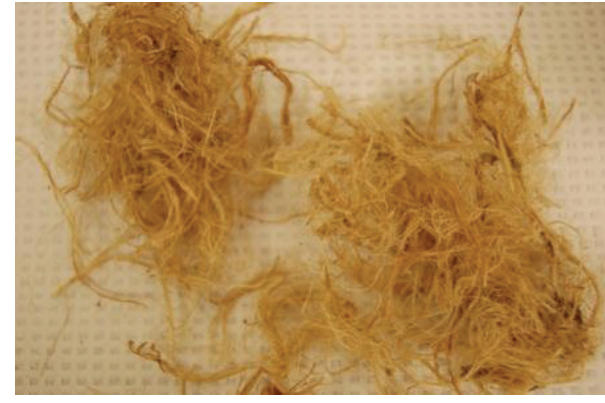

(a)

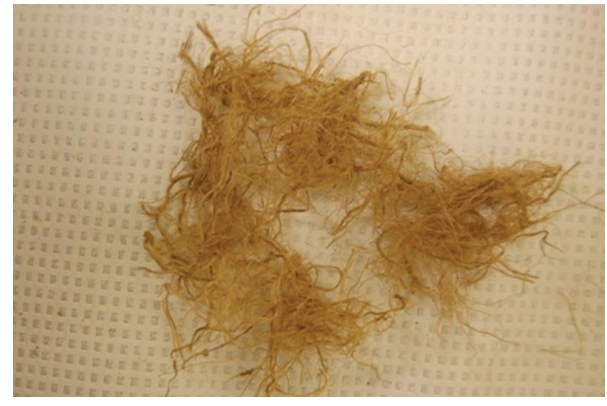

(c)

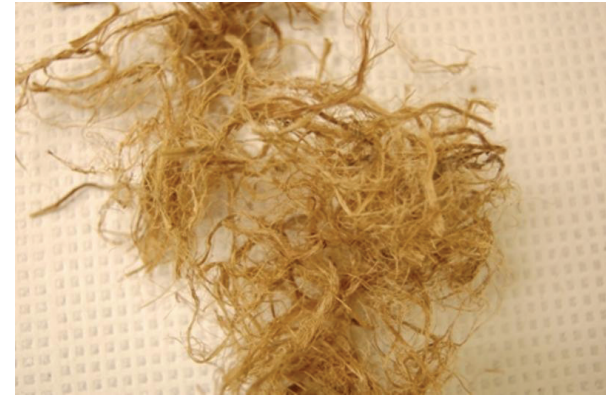

(b)

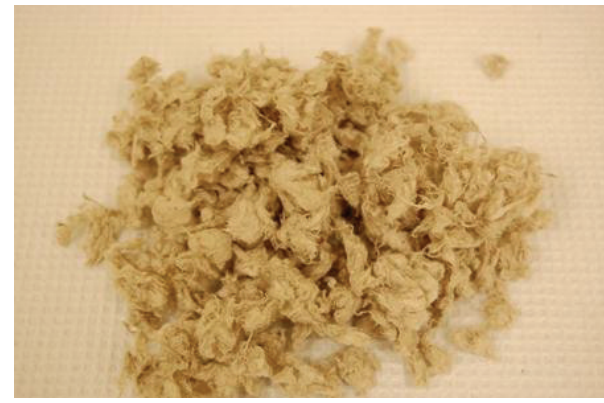

(d)

Figure 1: Images of the fibers digested at (a) $80^{\circ} \mathrm{C}$, (b) $110^{\circ} \mathrm{C}$, (c) $130^{\circ} \mathrm{C}$, and (d) $160^{\circ} \mathrm{C}$.

TABLE 2: Average and standard deviation of the fiber dimensions.

\begin{tabular}{lcccc}
\hline & & $\begin{array}{c}\text { Length } \\
(\mu \mathrm{m})\end{array}$ & $\begin{array}{c}\text { Diameter } \\
(\mu \mathrm{m})\end{array}$ & $\begin{array}{c}\text { Aspect } \\
\text { ratio }\end{array}$ \\
\hline $\begin{array}{l}\text { Digested at } 80^{\circ} \mathrm{C}, 110^{\circ} \mathrm{C} \text {, and } \\
130^{\circ} \mathrm{C} \text { with mechanical }\end{array}$ & Ave. $^{*}$ & 1578.8 & 20.3 & 89.0 \\
disintegration & Stdev. $^{*}$ & 524.8 & 9.4 & 41.7 \\
\hline Digested at $160^{\circ} \mathrm{C}$ & Ave. & 468.0 & 18.2 & 16.0 \\
& Stdev. & 575.5 & 6.4 & 15.1 \\
\hline
\end{tabular}

*Ave.: average of 70 samples. ${ }^{*}$ Stdev.: standard deviation.

The total amount of holocelluloses is gradually increased as the increase of the digestion temperature. The holocellulose content increased from $75.8 \%$ for the control fibers to $94.2 \%$ for the digested fibers at $160^{\circ} \mathrm{C}$. This increase in the total holocellulose content is probably related to the decrease of the lignin content. The total amount of pure cellulose in the fibers expressed by $\alpha$-cellulose is remarkably increased as the increase of digestion temperature. The amount of hemicelluloses remained in the digested fibers were significantly decreased as the increase of digestion temperature. The above results indicate that the alkali digestion process used in the study solubilized most of hemicelluloses and removed most of lignin from the fibers by increasing the digestion temperature.

3.2. Morphology. From the appearance of the fibers, those digested at $80^{\circ} \mathrm{C}, 110^{\circ} \mathrm{C}$, and $130^{\circ} \mathrm{C}$ were fiber bundles, which were bigger and longer compared with those digested at $160^{\circ} \mathrm{C}$ (Figure 1). The fiber bundles obtained at $80^{\circ} \mathrm{C}$, $110^{\circ} \mathrm{C}$, and $130^{\circ} \mathrm{C}$ were separated mechanically and made into fine fibers. Having been mechanically separated, these fibers have the same distribution in length, diameter, and aspect ratio, because they went through the same mechanical disintegration process. The fibers digested at $160^{\circ} \mathrm{C}$ were 
TABLE 3: Surface hardness and elastic modulus of digested fibers.

\begin{tabular}{|c|c|c|c|c|}
\hline & $80^{\circ} \mathrm{C}$ & $110^{\circ} \mathrm{C}$ & $130^{\circ} \mathrm{C}$ & $160^{\circ} \mathrm{C}$ \\
\hline \multicolumn{5}{|c|}{ Surface hardness (MPa) } \\
\hline Ave.* & 64.25 & 179.50 & 224.74 & 287.91 \\
\hline Stdev.* & 45.23 & 124.07 & 31.88 & 113.75 \\
\hline LSD test & A & B & B & $\mathrm{B}$ \\
\hline \multicolumn{5}{|c|}{ Elastic modulus (GPa) } \\
\hline Ave. & 2.48 & 3.19 & 4.98 & 5.24 \\
\hline Stdev. & 1.15 & 1.68 & 0.25 & 1.59 \\
\hline LSD test & $\mathrm{A}$ & $A, B$ & $\mathrm{~B}, \mathrm{C}$ & $\mathrm{C}$ \\
\hline
\end{tabular}

* Ave.: average of four samples. Stdev.: standard deviation. Means with the different letter are significantly different at $\alpha=0.05$.

TABLE 4: Tensile properties of individual digested fibers.

\begin{tabular}{|c|c|c|c|c|c|c|}
\hline Temperatures $\left({ }^{\circ} \mathrm{C}\right)$ & Modulus (GPa) & LSD test & Strength (MPa) & LSD test & Elongation (\%) & LSD test \\
\hline 110 & 23.6 & A & 1051 & A & 4.5 & A \\
\hline 160 & 13.5 & $\mathrm{~B}$ & 810 & B & 5.6 & $\mathrm{~B}$ \\
\hline
\end{tabular}

Average of 30 samples. Means with the different letter are significantly different a $\alpha=0.05$.

fine individual fibers and were not subjected to mechanical separation. The distributions of the dimensions are shown in Figure 2. The average and its standard deviation of the dimensions are shown in Table 2.

After the mechanical separation, the lengths of the fibers digested at $80^{\circ} \mathrm{C}, 110^{\circ} \mathrm{C}$, and $130^{\circ} \mathrm{C}$ ranged from 0.5 and $2.6 \mathrm{~mm}$. The lengths of the fibers digested at $160^{\circ} \mathrm{C}$ were between 0.05 to $0.87 \mathrm{~mm}$, which was much smaller compared to the other fibers. However, the fibers digested at $80^{\circ} \mathrm{C}$, $110^{\circ} \mathrm{C}$, and $130^{\circ} \mathrm{C}$ had aspect ratios ranging from 24 to 148 , which were higher than those digested at $160^{\circ} \mathrm{C}$.

Figure 3 shows the SEM images of the digested fibers. The micropores were seen in Figure 3 in cell wall structures of the fibers digested at $130^{\circ} \mathrm{C}$ and $160^{\circ} \mathrm{C}$. The generated micropores are due to the removal of hemicelluloses and lignin. The size of the micropores was about $50 \mathrm{~nm}$.

3.3. Surface Hardness and Elastic Modulus. Table 3 shows the results of surface hardness and elastic modulus of digested fibers tested by nanoindentation.

The higher the digestion temperature, the higher the hardness and elastic modulus were. The elastic modulus of the fibers digested at $160^{\circ} \mathrm{C}$ was two times higher than those digested at $80^{\circ} \mathrm{C}$, while the hardness of the fibers digested at $160^{\circ} \mathrm{C}$ was four times higher than those digested at $80^{\circ} \mathrm{C}$. This might be due to the increase of cellulose content and the decrease of lignin and hemicelluloses. Cellulose has more ordered crystalline structure than lignin and hemicelluloses, while lignin and hemicelluloses are in amorphous arrangement. The crystalline arrangement of the cellulose molecular chain may result in high surface hardness and elastic modulus [24]. However, cellulose also contains amorphous regions. Crystalline regions and amorphous regions alternately exist in a cellulose chain. Therefore, cellulose structure is not homogeneous. Moreover, the micropore distribution in the digested fibers is not uniform, known from the SEM images. The nonuniform structure of cellulose and the micropore distribution in the fibers resulted in big variations of the indentation results.

3.4. Tensile Properties of Individual Fibers. The tensile properties of the individual fibers digested at $100^{\circ} \mathrm{C}$ and $160^{\circ} \mathrm{C}$ are shown in Table 4.

Significant differences were observed between the tensile modulus, tensile strength, and elongation of the fibers digested at $110^{\circ} \mathrm{C}$ and $160^{\circ} \mathrm{C}$. The tensile modulus of the fibers digested at $110^{\circ} \mathrm{C}$ was $10.1 \mathrm{GPa}$ higher than that of the fibers digested at $160^{\circ} \mathrm{C}$. The fiber tensile strength reduced from $1,051 \mathrm{MPa}$ to $810 \mathrm{MPa}$ as the digestion temperature increased from $110^{\circ} \mathrm{C}$ to $160^{\circ} \mathrm{C}$. However, the elongation of the fibers digested at $160^{\circ} \mathrm{C}$ was $1.1 \%$ higher than that digested at $110^{\circ} \mathrm{C}$. The decrease in the tensile modulus and strength may be due to the removal of lignin and hemicelluloses. In the control kenaf fibers, lignin filled the spaces in the cell wall between cellulose and hemicelluloses. It is covalently linked to the hemicelluloses and thereby crosslinked the different polysaccharides. Thus, lignin conferred mechanical strength to the single fibers as a whole [25]. The removal of lignin and hemicelluloses resulted in a microporosity structure in the fiber cell wall and a loose connection between individual cellulose microfibrils in an individual fiber. Therefore, a lower tensile modulus and strength were obtained.

3.5. Mechanical Properties of Composites. The results of tensile modulus and tensile strength of the composites are shown in Table 5. Statistical analysis indicated that there was no significant difference in tensile modulus and tensile strength at the 95\% significance level among the four types of composites. 


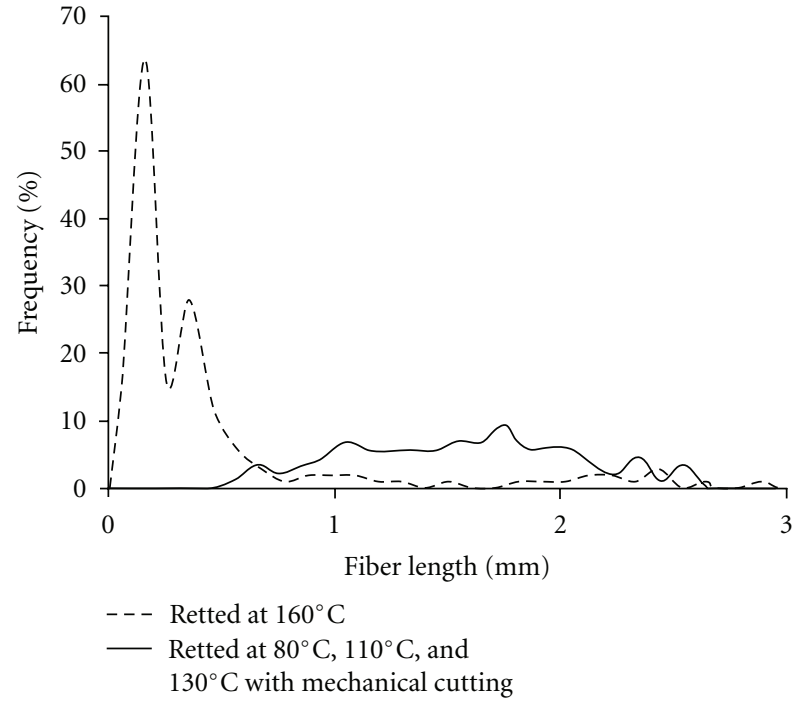

(a)

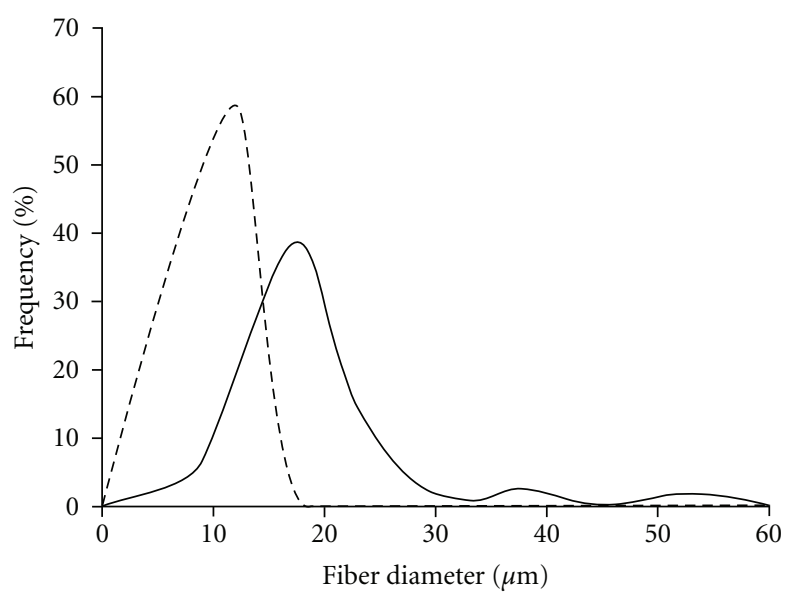

- - - Retted at $160^{\circ} \mathrm{C}$

- Retted at $80^{\circ} \mathrm{C}, 110^{\circ} \mathrm{C}$, and $130^{\circ} \mathrm{C}$ with mechanical cutting

(b)

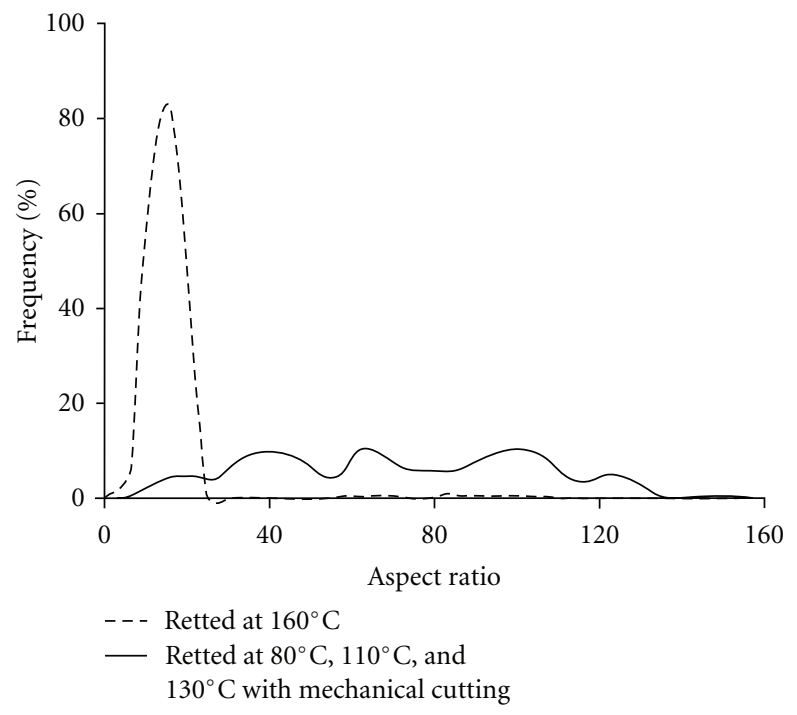

(c)

Figure 2: Dimensional distribution of the digested fibers. (a) length distribution, (b) diameter distribution, (c) aspect ratio distribution.

TABLE 5: Tensile properties of the kenaf fiber/PP composites.

\begin{tabular}{lcccccc}
\hline \multirow{2}{*}{ Digestion temperatures $\left({ }^{\circ} \mathrm{C}\right)$} & \multicolumn{3}{c}{ Tensile strength $(\mathrm{MPa})$} & \multicolumn{3}{c}{ Tensile modulus (GPa) } \\
& Ave. $^{*}$ & Stdev. $^{*}$ & LSD Test & Ave. & Stdev. & LSD Test \\
\hline $80^{\circ} \mathrm{C}$ & 42.44 & 7.12 & $\mathrm{~A}$ & 1.57 & 0.11 & $\mathrm{~A}$ \\
$110^{\circ} \mathrm{C}$ & 47.35 & 2.20 & $\mathrm{~A}$ & 1.53 & 0.09 & $\mathrm{~A}$ \\
$130^{\circ} \mathrm{C}$ & 45.20 & 3.57 & $\mathrm{~A}$ & 1.67 & 0.12 & $\mathrm{~A}$ \\
$160^{\circ} \mathrm{C}$ & 46.77 & 3.43 & $\mathrm{~A}$ & 1.70 & 0.20 \\
\hline
\end{tabular}

* Ave.: average of four samples. Stdev.: standard deviation. Means with the different letter are significantly different at $\alpha=0.05$. Average of 27 samples. Means with the same letter are not significantly different at $\alpha=0.05$. 


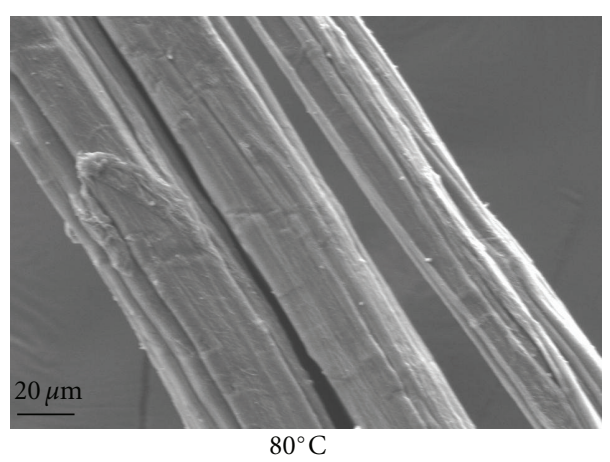

(a)

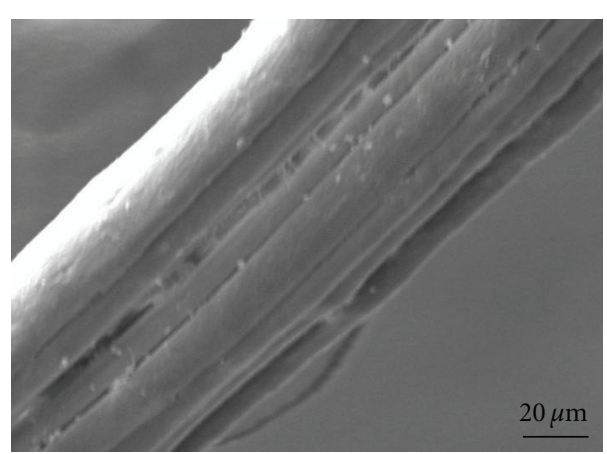

$130^{\circ} \mathrm{C}$

(c)

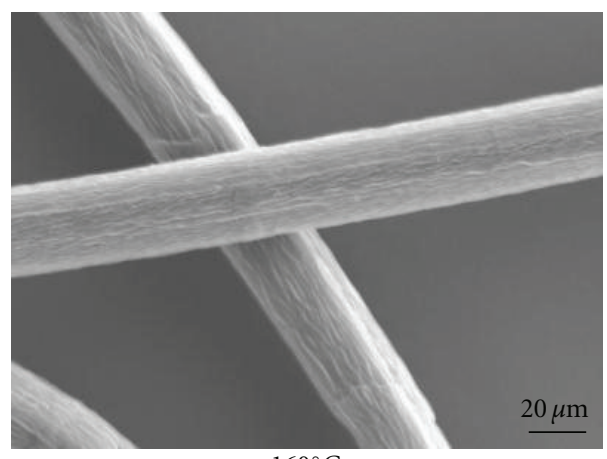

$160^{\circ} \mathrm{C}$

(e)

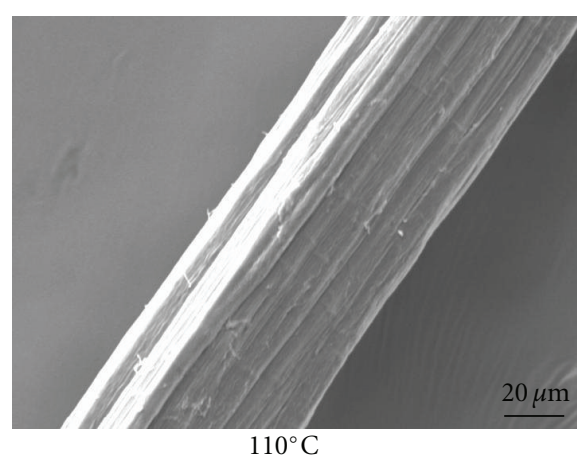

(b)

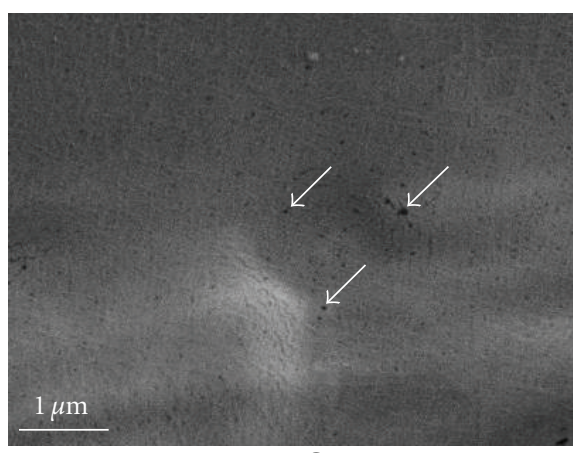

$130^{\circ} \mathrm{C}$

(d)

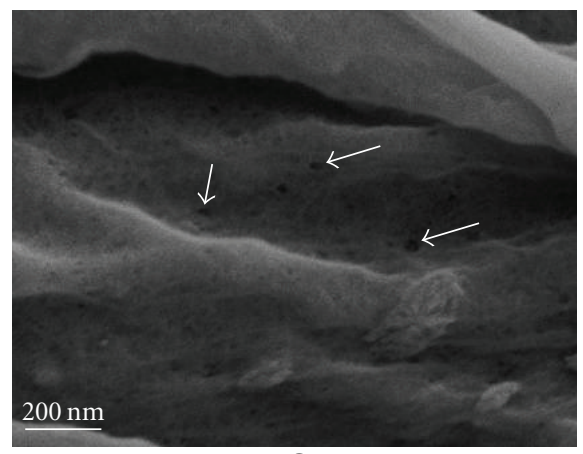

$160^{\circ} \mathrm{C}$

(f)

Figure 3: SEM images of the digested fibers. (The arrows designate the micropores).

Many factors may influence the reinforcement efficiency of the fibers including aspect ratio, chemical component, and surface characterization. Although the fibers digested at $160^{\circ} \mathrm{C}$ had a smaller aspect ratio than the other fibers, the resulting composites did not show a lower tensile modulus or tensile strength. This may be due to its higher cellulose content, which compensated the lower aspect ratio. The high cellulose content of the fibers resulted in a high fiber tensile modulus. More severe breakage of the fibers in the composite made from fibers digested at $160^{\circ} \mathrm{C}$ (Figure 4(a)) indicates a slightly better bondage between the fibers and the PP matrix but also probably resulted in their low strength at $160^{\circ} \mathrm{C}$
(Table 4). Generally, the fracture surface images (Figure 4) illuminated that the compatibility between the digested fibers and polypropylene was poor as evidenced by the complete separation between the fibers and polypropylene matrix. Therefore, surface modification for the digested fibers is necessary in order to improve the compatibility between the fibers and the PP matrix

\section{Conclusions}

Hermetical alkali digestion process effectively removed the lignin and hemicelluloses from kenaf bast fibers at $160^{\circ} \mathrm{C}$. 


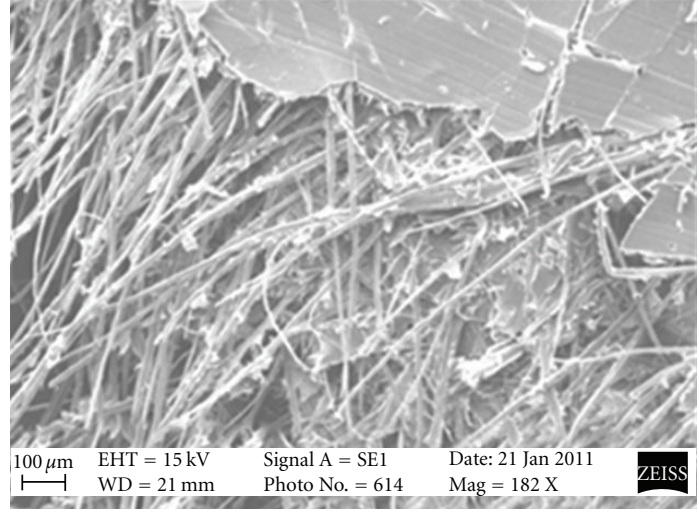

(a)

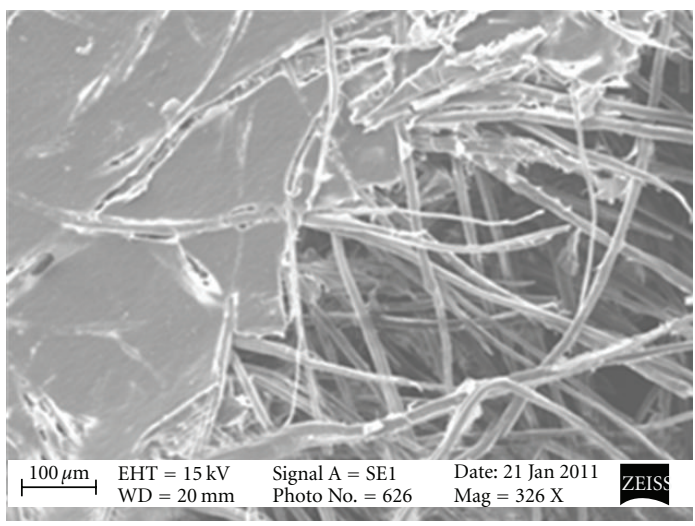

(c)

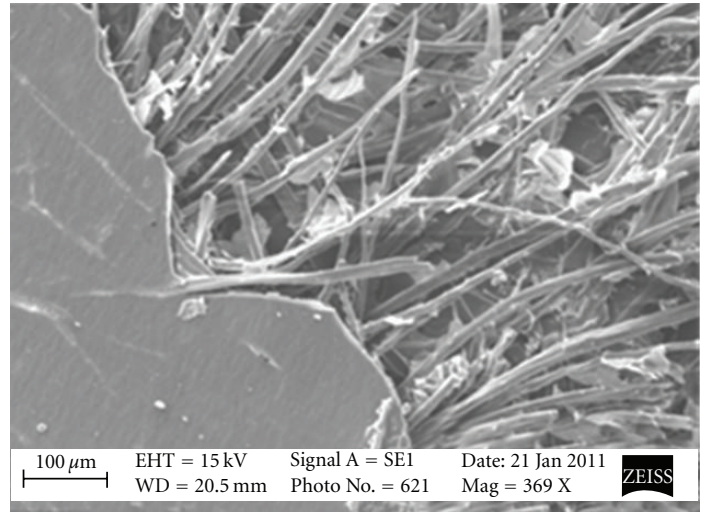

(b)

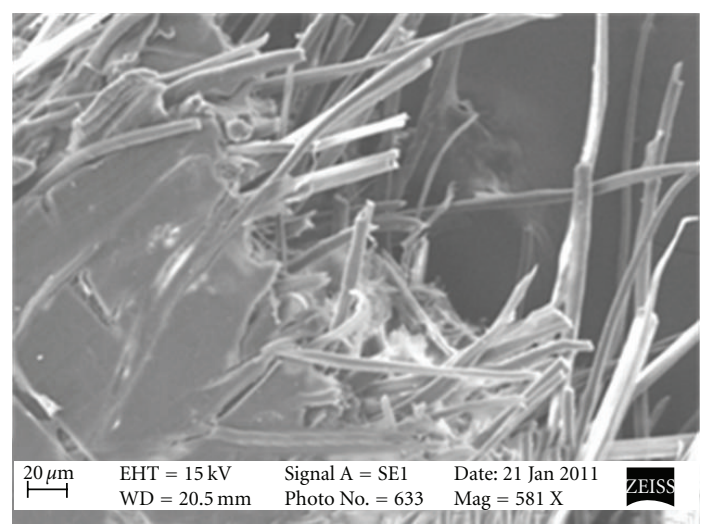

(d)

FIGURE 4: SEM images of the fracture surface of the PP composites reinforced with kenaf fibers digested at (a) $80^{\circ} \mathrm{C},(\mathrm{b}) 110^{\circ} \mathrm{C},(\mathrm{c}) 130^{\circ} \mathrm{C}$, and (d) $160^{\circ} \mathrm{C}$.

The $\alpha$-cellulose content of the fibers was $92 \%$. The average surface hardness and elastic modulus of the fiber digested at $160^{\circ} \mathrm{C}$ yielded improvement of $348.1 \%$ and $111.3 \%$, respectively, compared with those digested at $80^{\circ} \mathrm{C}$. The increase of cellulose content of the digested fibers resulted in an improved fiber surface hardness and elastic modulus. The digestion temperature had a significant effect on tensile modulus and tensile strength properties of the fiber. When the digestion temperature increased from $110^{\circ} \mathrm{C}$ to $160^{\circ} \mathrm{C}$, the tensile modulus and tensile strength of individual fibers were reduced by $42.8 \%$ and $22.9 \%$, respectively, while the elongation increased by $1.1 \%$. The SEM images showed that the micropores were generated in cell wall structures for the fibers digested at $130^{\circ} \mathrm{C}$ and $160^{\circ} \mathrm{C}$, providing the possibility to anchor nanoparticles into the cell wall. The digested fibers without surface modification had a poor interfacial compatibility with the polypropylene matrix.

\section{Acknowledgments}

The research work was supported by Department of Energy (DOE), funding \# 362000-060803 through Center for Advanced Vehicular System (CAVs) at Mississippi State
University and National Science Foundation (NSF), fund \# CMMI0928641 09080796. Acknowledgments are given to Dr. Sangyeob Lee for the involvement of the project when he worked as a postdoc at Mississippi State University, the USDA-Forest Service Southern Research Station, Pineville, LA, and the International Center for Bamboo and Rattan, Beijing, China for the instrumental support. The manuscript is approved for publication by Forest and Wildlife Research Center (FWRC), Mississippi State University. The FWRC Publication No.: FP610.

\section{References}

[1] A. F. Kaldor, C. Karlgren, and H. Verwest, "Kenaf-a fast growing fiber source for papermaking," Tappi Journal, vol. 73, no. 11, pp. 205-208, 1990.

[2] K. H. Song and S. K. Obendorf, "Chemical and biological retting of kenaf fibers," Textile Research Journal, vol. 76, no. 10, pp. 751-756, 2006.

[3] B. Aleksandra, B. G. Gordana, A. Grozdanov, M. Avella, G. Gentile, and M. Errico, "Crystallization behavior of poly(hydroxybytyrate-co-valerate) in model and bulk PHBV/kenaf fiber composites," Journal of Materials Science, vol. 42, no. 16, pp. 6501-6509, 2007. 
[4] T. A. Bullions, D. Hoffman, R. A. Gillespie, J. P. Brien, and A. C. Loos, "Contributions of feather fibers and various cellulose fibers to the mechanical properties of polypropylene matrix composites," Composites Science and Technology, vol. 66, no. 1, pp. 102-114, 2006.

[5] C. Clemons and A. R. Sanadi, "Instrumented impact testing of kenaf fiber reinforced polypropylene composites: effects of temperature and composition," Journal of Reinforced Plastics and Composites, vol. 26, no. 15, pp. 1587-1602, 2007.

[6] J. M. Park, T. Q. Son, J. G. Jung, and B. S. Hwang, "Interfacial evaluation of single ramie and kenaf fiber/epoxy resin composites using micromechanical test and nondestructive acoustic emission," Composite Interfaces, vol. 13, no. 2-3, pp. 105-129, 2006.

[7] T. Nishino, K. Hirao, M. Kotera, K. Nakamae, and H. Inagaki, "Kenaf reinforced biodegradable composite," Composites Science and Technology, vol. 63, no. 9, pp. 1281-1286, 2003.

[8] S. H. Aziz, M. P. Ansell, S. J. Clarke, and S. R. Panteny, "Modified polyester resins for natural fibre composites," Composites Science and Technology, vol. 65, no. 3-4, pp. 525535,2005

[9] S. Keshk, W. Suwinarti, and K. Sameshima, "Physicochemical characterization of different treatment sequences on kenaf bast fiber," Carbohydrate Polymers, vol. 65, no. 2, pp. 202-206, 2006.

[10] H. J. Lee, Y. S. Han, H. J. Yoo, J. H. Kim, K. H. Song, and C. S. Ahn, "Effect of chemical retting on the fiber separation of kenaf bast," Journal of the Korean Society of Clothing and Textiles, vol. 27, no. 9-10, pp. 1144-1152, 2003.

[11] W. H. Morrison, D. E. Akin, G. Ramaswamy, and B. Baldwin, "Evaluating chemically retted kenaf using chemical, histochemical, and microspectrophotometric analyses," Textile Research Journal, vol. 66, no. 10, pp. 651-656, 1996.

[12] D. V. Parikh, T. A. Calamari, A. P. S. Sawhney et al., "Improved chemical retting of kenaf fibers," Textile Research Journal, vol. 72, no. 7, pp. 618-624, 2002.

[13] J. Wang and G. N. Ramaswamy, "Physical and chemical properties of wet processed hemp and kenaf," AATCC Review, vol. 5, no. 1, pp. 22-26, 2005.

[14] G. N. Ramaswamy, C. G. Ruff, and C. R. Boyd, "Effect of bacterial and chemical retting on kenaf fiber quality," Textile Research Journal, vol. 64, no. 5, pp. 305-308, 1994.

[15] A. P. Deshpande, M. B. Rao, and C. L. Rao, "Extraction of bamboo fibers and their use as reinforcement in polymeric composites," Journal of Applied Polymer Science, vol. 76, no. 1, pp. 83-92, 2000.

[16] G. G. Allan, J. P. Carroll, A. R. Negri, M. Raghuraman, P. Ritzenthaler, and A. Yahiaoui, "The microporosity of pulp: the precipitation of inorganic fillers within the micropores of the cell wall," Tappi Journal, vol. 75, no. 1, pp. 175-178, 1992.

[17] TAPPI T 211 om-93, "Ash in wood, pulp, paper and paperboard: combustion at 525 degrees Celsius," Tappi Standards, 1993.

[18] The Institute of Paper Chemistry, Method no. 428, The Institute of Paper Chemistry, Appleton, Wis, USA, 1951.

[19] L. E. Wise, M. Murphy, and A. D. Addieco, "Chlorite holocellulose, its fractionation and bearing on summative wood analysis and on studies on the hemicelluloses," Paper Trade Journal, vol. 122, no. 2, pp. 35-43, 1946.

[20] Markblatt (IV/29 Zellcheming), "Bestimmung der Alphacellulose und de langeunloslichen Anteils von Zellstoffen," German Association of Cellulose Chemists and Engineers, 1951.

[21] W. C. Oliver and G. M. Pharr, "Improved technique for determining hardness and elastic modulus using load and displacement sensing indentation experiments," Journal of Materials Research, vol. 7, no. 6, pp. 1564-1580, 1992.

[22] G. Wang, Y. Yu, S. Q. Shi, J. Wang, S. Cao, and H. Cheng, "A micro-tension test method for measuring tensile properties of individual cellulosic fibers," Wood and Fiber Science. In press.

[23] ASTM D1037-06a, "Standard test methods for evaluating properties of wood-base fiber and particle panel materials," ASTM International, 2006.

[24] P. Zadorecki and A. J. Michell, "Future prospects for wood cellulose as reinforcement in organic polymer composites," Polymer Composites, vol. 10, no. 2, pp. 69-77, 1989.

[25] M. Chabannes, K. Ruel, A. Yoshinaga et al., "In situ analysis of lignins in transgenic tobacco reveals a differential impact of individual transformations on the spatial patterns of lignin deposition at the cellular and subcellular levels," The Plant Journal, vol. 28, no. 3, pp. 271-282, 2001. 

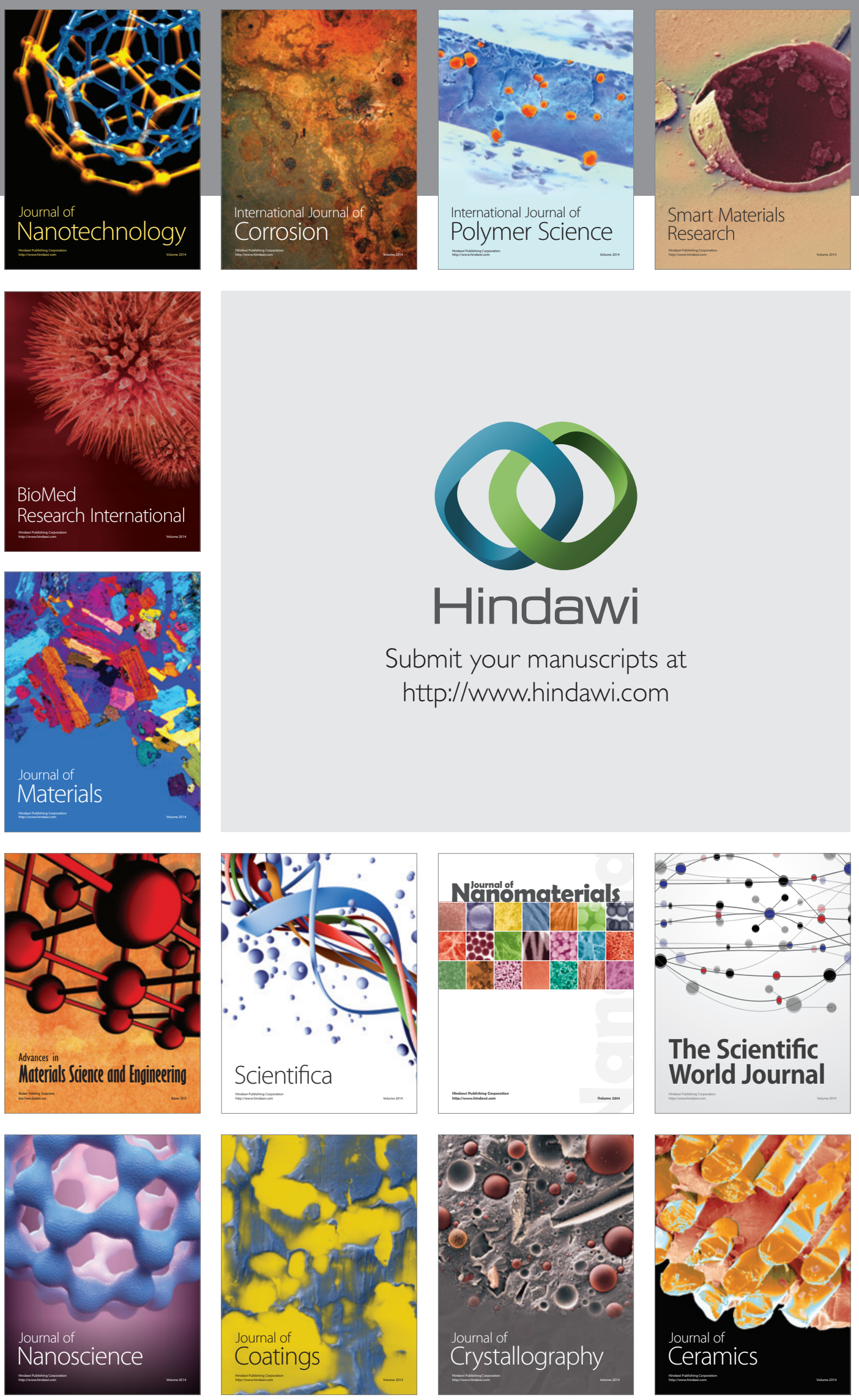

The Scientific World Journal

Submit your manuscripts at

http://www.hindawi.com

\section{World Journal}

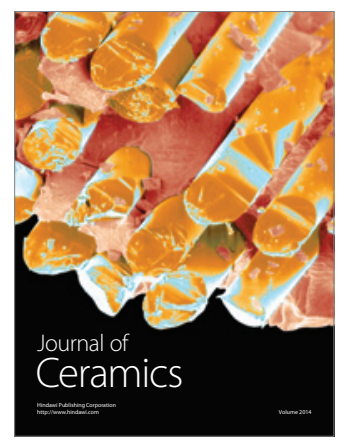

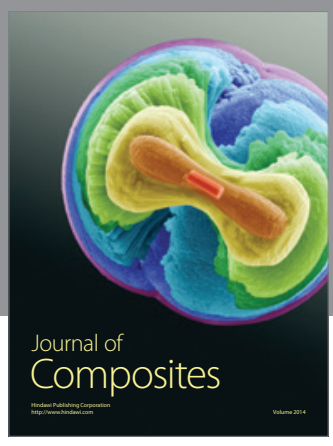
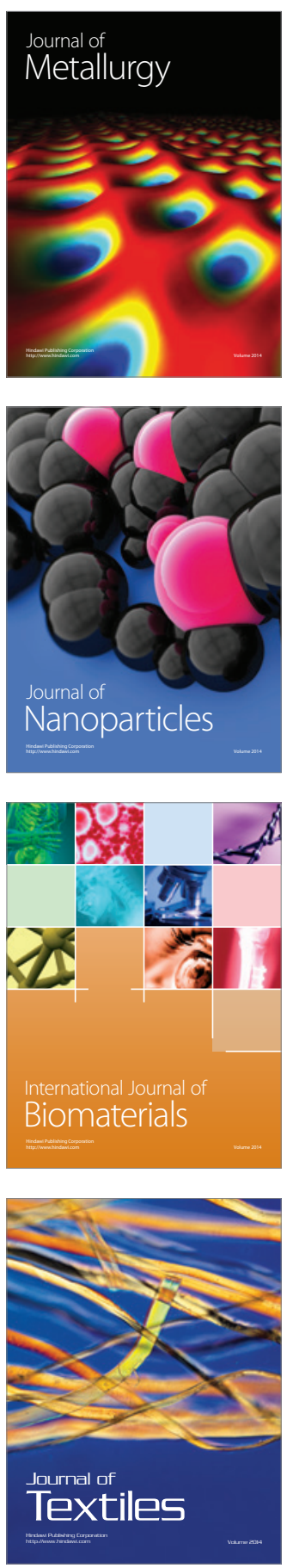